\title{
A Case of Mammary-Type Myofibroblastoma of the Tongue
}

\author{
Jin Su Park, Yong Woo Lee, Sang Hyuk Lee, and Sung Min Jin \\ Department of Otorhinolaryngology-Head and Neck Surgery, Kangbuk Samsung Hospital, \\ Sungkyunkwan University School of Medicine, Seoul, Korea
}

혀에 발생한 유방형 근섬유모세포종 1예

박진수 · 이용우 · 이상혁 · 진성민

성균관대학교 의과대학 강북삼성병원 이비인후과학교실

Received July 15, 2016

Revised September 5, 2016

Accepted September 9, 2016

Address for correspondence

Sung Min Jin, MD

Department of Otorhinolaryngology-

Head and Neck Surgery,

Kangbuk Samsung Hospital,

Sungkyunkwan University

School of Medicine,

29 Saemunan-ro, Jongno-gu,

Seoul 03181, Korea

Tel $+82-2-2001-2269$

Fax $+82-2-2001-2273$

E-mailsm7.jin@samsung.com
A mammary-type myofibroblastoma is a rare benign mesenchymal neoplasm composed of spindle cells initially described to occur in the breast. However, they also arise at extra-mammary sites including the inguinal area, breast, chest wall/axilla, trunk, upper and lower extremities, and head and neck regions. In particular, mammary-type myofibroblastoma of the head and neck are extremely rare and may occur at any age. Immunohistochemically, it is typically CD34 and desmin positive. Currently, complete excision is considered as the first line treatment and recurrence of the tumor is rare. We experienced a 41-year-old man who visited with $1 \mathrm{~cm}$ sized firm mass of the tongue. The mass was resected and tissue biopsy revealed a diagnosis of mammary-type myofibroblastoma. Herein we report a rare case of mammarytype myofibroblastoma of the tongue with a review of the literature.

Korean J Otorhinolaryngol-Head Neck Surg 2018;61(2):103-5

Key Words Myofibroblastoma · Tongue.

\section{서 론}

유방형 근섬유모세포종(mammary-type myofibroblastoma) 은 근섬유모세포 형태의 방추형세포들이 유리화된 기질로 둘 러싸인 매우 드문 형태의 양성 간질 종양으로, 유방의 연부조 직에서 발생하는 종양이다. 1987년 처음으로 Wargotz 등'이 유방에 발생한 근섬유모세포종을 보고하였다. 유방 이외의 부위에서도 발생하는 것으로 알려져 있으며, 주로 서혜부에 서 관찰되며 흥벽, 복벽, 엉덩이, 등, 질 후벽, 다리오금, 치골 상 피하조직 및 골반강 내 종괴의 형태로 발견된 경우가 있었 다. ${ }^{2,3)}$ 문헌 고찰 두경부 영역에서 발견된 경우는 극히 드물 며, 세계적으로 하악골 2예, 후두 2예, 귓바퀴 아래 부위 1예,

This is an Open Access article distributed under the terms of the Creative Commons Attribution Non-Commercial License (http://creativecommons.org/licenses/by-nc/4.0) which permits unrestricted non-commercial use, distribution, and reproduction in any medium, provided the original work is properly cited.
그리고 혀에 발생한 경우는 2예가 보고되었고, 아직까지 국 내에서는 악하선 부위에 생긴 1예 외에는 없었다. ${ }^{4-9)}$

이에 저자들은 41세 남자 환자에서 좌측 혀에 발생한 유방 형 근섬유모세포종을 경험하였기에 문헌 고찰과 함께 보고 하고자 한다.

\section{증 려}

41세 남자 환자가 3 주 전 발견된 좌측 혀의 종괴를 주소로 내원하였다. 환자는 통증, 이물감 등의 다른 증상은 호소하지 않고 있었으며, 신체 진찰에서 혀의 좌측 변연부에 $1 \mathrm{~cm}$ 크기 의 비교적 경계가 명확하며 단단한 백색의 돌출성 종괴가 관 찰되었다(Fig. 1). 압통, 발적, 열감 등의 감염 및 염증을 시사 하는 소견은 보이지 않았다. 경부, 비강, 구강 내의 다른 부위 에 병변은 관찰되지 않았으며, 혀의 움직임에는 문제가 없었 
다. 병변의 심부 침범 및 범위를 확인하기 위해서 경부전산화 단층촬영을 시행하였으나 크기가 작고 치아의 금속 보철물 에 의한 인공음영(artifact)으로 인해 병변을 확인할 수 없었 으며 경부 자기공명영상 역시 병변을 확인할 수 없을 것으로 생각되어 시행하지 않았다.

섬유종, 점액류, 유두종 등 구강설의 양성 병변을 의심하여 정확한 진단을 위해 혀의 병변에 대하여 수술적 절제를 계획 하였다. 전신마취하에 denhardt mouth gag를 이용하여 입을 벌려 구강설을 노출시킨 후 병변을 확인하였다. 이후 병변의 경 계를 확인하며 cold knife를 이용하여 조심스럽게 박리를 하 였다. 병변은 주변 조직에 유착 없이 비교적 쉽게 절제되었으 며 출혈이나 부종 등의 합병증은 발생하지 않았다.

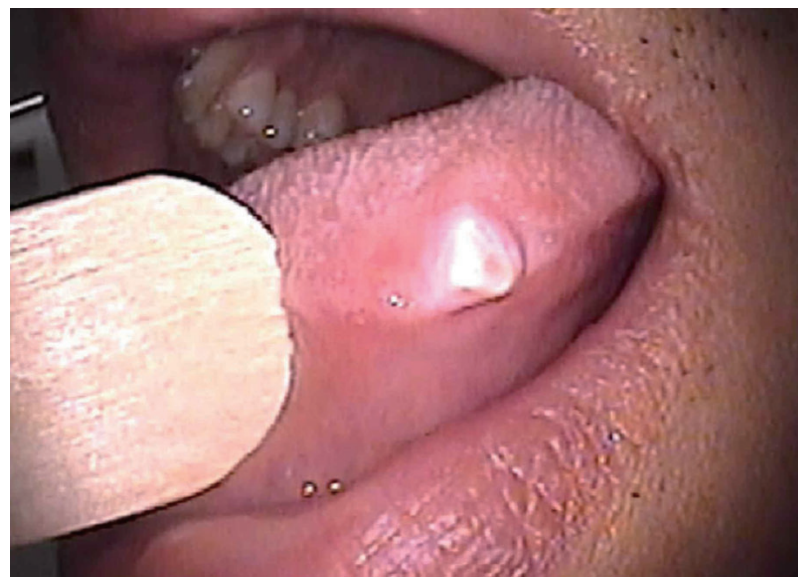

Fig. 1. Photograph of tongue mass, whitish and firm protruding mass was observed at left lateral border of oral tongue.
수술 시에 시행한 조직검사에서 근원성의 분화를 보이는 침윤성의 방추형세포들이 다발형 및 나선형의 형태로 주행 하는 모습이 관찰되었다. 비전형 유사분열과 세포괴사는 관 찰되지 않았으며, 절제 면에서 종양의 증거는 발견되지 않았 다. 면역 염색에서 desmin, vimentin, CD68은 양성 소견을 보 였으며 CD34, smooth muscle actin(SMA)에 국소 양성반응 을 보였지만 S-100에 음성반응을 보였다(Fig. 2). 이러한 조 직 소견 및 면역염색 소견에 기초하여 유방형 근섬유모세포 종으로 진단하였다.

수술 후 1 일째에 별다른 합병증 없이 퇴원하였고 외래 추 적관찰을 하였다. 수술적 치료 시행 후 1 주, 1 개월 후 외래 내 원하였으며 신체 진찰에서 완전히 회복된 상태로 병변의 흔 적은 관찰되지 않았으며, 합병증 및 재발 소견 또한 관찰되지 않았다. 추후 3 개월, 1 년째에 외래 관찰을 통하여 재발의 여 부를 확인할 예정이다.

\section{고 찰}

1987년 처음으로 Wargotz 등'이 유방의 연부조직에 발생 한 근섬유모세포종을 보고한 이후 2001년에 McMenamin과 Fletcher ${ }^{3}$ 가 유방 이외에서 발생한 근섬유모세포종 9예에 대 해 보고하였다. 근섬유모세포종은 초기에 유방에 발생하는 것으로 보고되었으나 최근 유방 이외의 부위에서도 발생하 는 것으로 알려져 이를 유방형 근섬유모세포종이라 지칭하 고 있다. 2016년에 Howitt과 Fletcher ${ }^{2}$ 가 보고한 143예의 근

Fig. 2. Histopathologic findings, H\&E stains showed that the tumor is composed of interlacing bundles of spindle shape or oval cells with hyalinized stroma and collagen fibers, and show myogenic differentiation $(\times 200)(A)$. Immunohistochemical stains showed negative for $\mathrm{S} 100(\times 200)(\mathrm{B})$, positive for des$\min (\times 200)(C)$, and vimentin $(\times 200)$ (D).
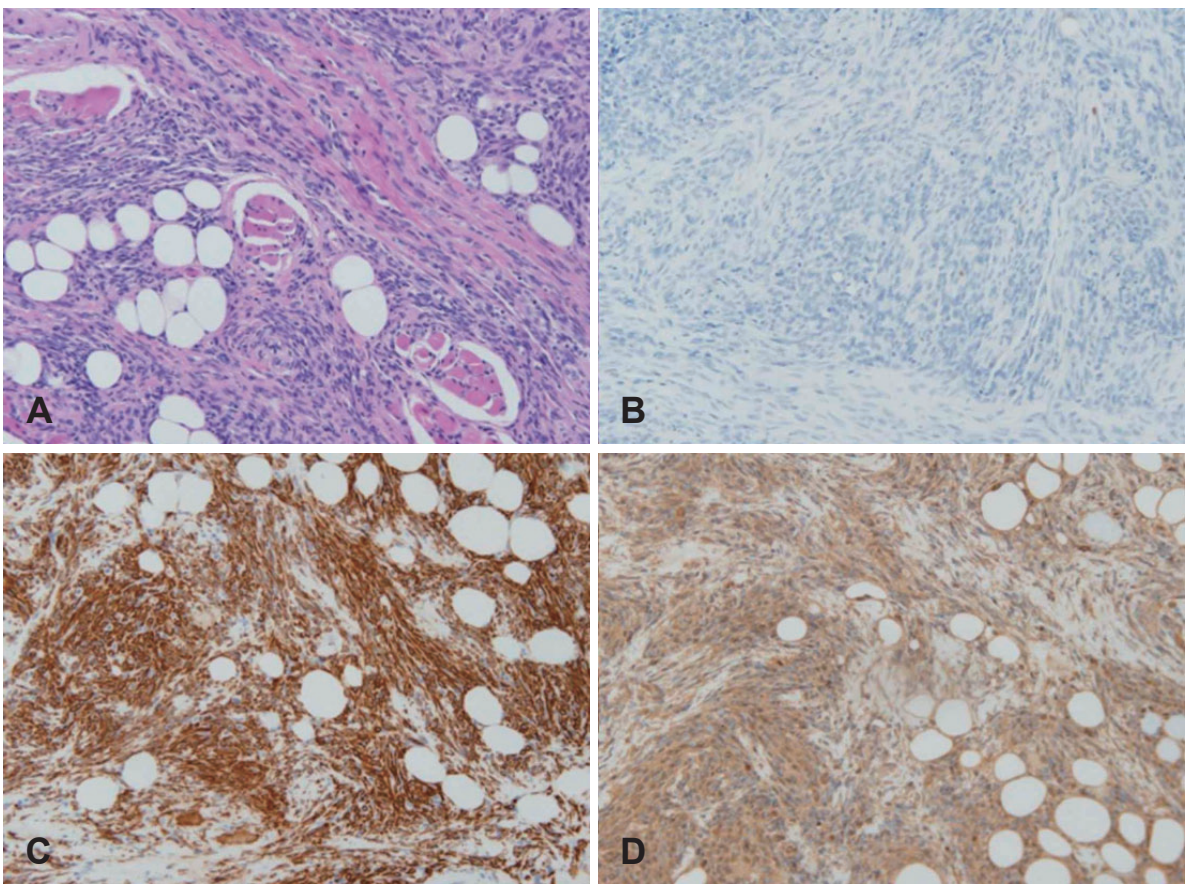
섬유모세포종에 대한 연구에서는 남성 94명(66\%), 여성 49명 (34\%)으로 나타났으며, 평균 나이 54세(4 96세)로 모든 연령 대에서 나타날 수 있는 것으로 나타났다. 발생에 대한 전신적 인 분포는 유방 15예(10\%), 서혜부 65예(45\%), 흥벽/겨드랑이 7예(5\%), 체간 17예(12\%), 하지 18예(13\%), 상지 2예(1\%), 복부 내/후복강 14예(10\%), 질내 2예(1\%), 두경부 영역 3예(2\%)로 나타났다. ${ }^{2)}$ 젖능선을 따라서 존재하는 부유방에서 발생하는 경향을 보이며 서혜부에서 가장 흔하게 발생된다는 보고가 있 었지만 등, 엉덩이, 다리오금 등의 병변에서 발생한 경우 젖능 선을 따라서 발생한다고는 설명하기 어려운 점이 있다. 특히, 두경부 영역에서 발견된 경우는 극히 드물며, 세계적으로 하 악골 2예, 후두 2예, 귓바퀴 아래 부위 1예, 그리고 혀에 발생 한 경우는 2예가 보고되었고, 아직까지 국내에 보고된 예는 악하선 부위에 생긴 1 예 외에는 없었다. ${ }^{4-9)}$

검체의 육안소견으로는 경계가 좋으며, 표면은 백색 혹은 황색을 띠고 다양한 정도의 지방질을 함유하고 있다. 조직학 적으로는 짧은 핵과 희미하고 창백한 세포질의 경계를 갖는 가느다란 섬유모세포 형태의 방추형세포들이 무계획적으로 작은 다발로 배열되며, 이는 두꺼운 콜라겐 다발에 의해 나 뉘는 모습을 보인다. 기질의 유리화 및 점액성 변화는 비교적 흔하게 나타난다. 비정형 세포는 매우 드물게 국소적으로 관 찰되며, 비정형 세포 분열은 관찰되지 않는다. 비만세포가 종 종 관찰되며, 지방세포도 드물지 않게 관찰되고 때로는 종양 의 절반 이상을 차지하기도 하며 다양한 정도의 지방세포 분 포를 보인다. 드물게 유상피세포, 점액성 변화, 다핵세포, 산 재된 비정형 세포가 관찰되기도 한다. ${ }^{2}$

면역 염색에서는 다양한 양상의 반응을 보일 수 있다. Des$\min$ 과 $\mathrm{CD} 34$ 에서 각각 $91 \%, 89 \%$ 의 양성반응을 보이며, des$\min , \mathrm{CD} 34$ 에서 모두 양성을 보이는 경우는 $84 \%$ 까지 보고 되고 있으나 $3 \%$ 미만에서 두가지 모두 음성을 보이는 경우도 있다. 또한, SMA와 S-100는 각각 $37 \%, 8 \%$ 의 환자에서 양성 반응을 보인다. ${ }^{2)}$

현재까지 비교적 예후가 좋고 재발률은 낮은 편으로 Howitt 와 Fletcher ${ }^{2}$ 에 의한 보고에서 54 명의 환자들에 대한 경과 관 찰에서 최종 경과 관찰 시(평균 경과 관찰 기간: 28.8 개월)에 94\%(51명)의 생존율을 보였고, 1 명(1.9\%)만 재발을 보였으며 절제 변연에서 종양의 증거를 보였던 8 명의 환자들에게서 재 발을 보이지 않아 완전한 절제가 이루어지지 않더라도 재발
률은 높지 않을 것으로 생각된다.

본 증례에서는 41 세의 남자 환자에게서 유방형 근섬유모세 포종의 빈도가 극히 낮은 구강의 혀에 생긴 1 예를 경험하였 다. 백색의 표면을 띠고 있었고 수술 시에 비교적 좋은 경계 를 확인할 수 있었으며, 조직검사에서 침윤성의 방추형세포 들이 다발형의 형태로 주행하는 모습이 관찰되며 면역염색 에서 desmin, vimentin은 모두 양성 소견을 보여 비교적 쉽게 진단을 할 수 있었다. 이 질환의 진단은 병리 소견과 함께 면 역조직화학염색을 통해 진단이 가능하지만 환자에 따라 비 전형적인 면역조직화학염색의 결과가 나타날 수 있어 진단에 어려움이 있을 수 있으므로 주의를 기울여야 할 것이다. 크기 의 증가가 느리고 주변 조직으로의 침윤이 없어 좋은 예후를 예상할 수 있지만, 3 세 남아의 우측 하악골에 발생하였던 유 방형 근섬유모세포종의 경우에는 크기가 빠르게 증가하며 하악골을 파괴하여 우측 반측하악골절제술이 필요한 경우 도 보고되어) 수술 후에 주기적인 경과 관찰이 필요할 것으로 생각된다.

\section{REFERENCES}

1) Wargotz ES, Weiss SW, Norris HJ. Myofibroblastoma of the breast. Sixteen cases of a distinctive benign mesenchymal tumor. Am J Surg Pathol 1987;11(7):493-502.

2) Howitt BE, Fletcher CD. Mammary-type myofibroblastoma: clinicopathologic characterization in a series of 143 cases. Am J Surg Pathol 2016;40(3):361-7.

3) McMenamin ME, Fletcher CD. Mammary-type myofibroblastoma of soft tissue: a tumor closely related to spindle cell lipoma. Am J Surg Pathol 2001;25(8):1022-9.

4) Hajeri S, Al Jabab A, Al Sheddi M, Fatani H. Myofibroblastoma of the mandible in a 3-year-old child. Oral Maxillofac Surg 2016;20(1): 103-7.

5) Sahin AA, Ro JY, Ordoñez NG, Luna MA, el-Naggar AK, Goepfert $\mathrm{H}$, et al. Myofibroblastoma of the tongue. An immunohistochemical, ultrastructural, and flow cytometric study. Am J Clin Pathol 1990; 94(6):773-7.

6) Bang KH, Choi JS, Lim JY, Kim L. A case of myofibroblastoma in the submandibular region. Korean J Otolaryngol-Head Neck Surg 2014;57(9):620-2.

7) Hamada T, Hirano M, Semba I, Kamikawa Y, Sugihara K. Myofibroblastoma of the tongue: a case report with immunohistochemical findings. J Oral Maxillofac Surg, Med Pathol 2012;24(3):180-3.

8) Hox V, Vander Poorten V, Delaere PR, Hermans R, Debiec-Rychter M, Sciot R. Extramammary myofibroblastoma in the head and neck region. Head Neck 2009;31(9):1240-4.

9) MacGregor AR, Batsakis JG, El-Naggar AK. Myofibroblastoma of the larynx: a study of two cases. Head Neck 2003;25(7):606-11. 